\title{
Meeting between kingdoms: discovery of a close association between Diplopoda and Bryophyta in a transitional Andean-Pacific forest in Colombia
}

\author{
Shirley Daniella Martínez-Torres', Álvaro Eduardo Flórez Daza², \\ Edgar Leonardo Linares-Castillo
}

I Biology Department, Universidad Nacional de Colombia, Ciudad Universitaria, Bogotá, Colombia 2 Instituto de Ciencias Naturales, Universidad Nacional de Colombia, Ciudad Universitaria, Bogotá, Colombia

Corresponding author: Shirley Daniella Martinez Torres (sdmartinezt@unal.edu.co)

Academic editor:R. Mesibov| Received 2 November 2011 | Accepted 30 November 2011 | Published 20 December 2011

Citation: Martínez-Torres SD, Flórez Daza ÁE, Linares-Castillo EL (2011) Meeting between kingdoms: discovery of a close association between Diplopoda and Bryophyta in a transitional Andean-Pacific forest in Colombia. In: Mesibov R, Short M (Eds) Proceedings of the 15th International Congress of Myriapodology, 18-22 July 2011, Brisbane, Australia. International Journal of Myriapodology 6: 29-36. doi: 10.3897/ijm.6.2187

\begin{abstract}
In a Nature Reserve called Reserva Natural Río Nambí (Narińo, Colombia), a platyrhacid millipede population of Psammodesmus bryophorus Hoffman, Martínez \& Flórez, 2011 was discovered with 10 epizoic bryophyte species from five families: Fissidentaceae, Lejeuneaceae, Metzgeriaceae, Leucomiaceae and Pilotrichaceae. The inspected sample included 22 P. bryophorus individuals of which 15 were carrying mosaics of different bryophyte species on their dorsa, principally Lepidopilum scabrisetum, Lejeunea sp. 1 and Fissidens weirii. This finding constitutes the first record of epizoic plants on Diplopoda.
\end{abstract}

\section{Keywords}

Diplopoda, Platyrhacidae, Psammodesmus, bryophytes, epizoic, Colombia

\section{Introduction}

Plants that live on living animals are known as epizoic plants. This type of plant has normally been found on tropical vertebrates and is unusual among terrestrial organ-

Copyright S. Daniela Martínez T. et al. This is an open access article distributed under the terms of the Creative Commons Attribution License 3.0 (CC-BY), which permits unrestricted use, distribution, and reproduction in any medium, provided the original author and source are credited. 
isms (Machado and Vital 2001). Concerning arthropods, a few epizoic plants have been reported on some weevils and on a single harvestman species from tropical countries (Gradstein et al. 1984, Gressitt 1966, Gressitt et al. 1968, Gressitt and Sedlacek 1970, Machado and Vidal 2001). These authors have reported epizoic bryophytes belonging to the Hookeriaceae, Lejeuneaceae and Metzgeriaceae families found in cloud and rain forests in New Guinea, México, and Brazil.

Another type of relationship is that of zoochory, only recorded in moss families located in temperate regions: Splachnaceae, whose spores are dispersed by Diptera in Europe (Koponen 1990, Lloret 1990) and Chile (Jofre et al. 2011), and Schistostegaceae, by several arthropods (spiders, insects) in Europe (Ignatov and Ignatova 2001), or liverworts and Cyanobacteria by Arachnida (Machado and Vital 2001) and Algae and bryophytes by lizards (Gradstein and Equihua 1995) in México, and mosses by Coleoptera in Oceania (Gradstein et al. 1984).

The present contribution focuses on the first report of epizoic bryophytes on diplopods and the first case of tropical bryophyte entomochory on the backs of diplopods. We show in detail the richness and abundance of epizoic bryophytes on the platyrhacid Psammodesmus bryophorus Hoffman, Martínez and Flórez, 2011 and report three bryophyte families previously unreported as epizoic plants.

\section{Methods}

Field work was done at the "Reserva Natural Río Nambi" (Fig. 1), located in southwest Colombia near the border with Ecuador, ca $50 \mathrm{~km}$ south of Barbacoas and ca $165 \mathrm{~km}$ west of Pasto $\left(1^{\circ} 18^{\prime} \mathrm{N}, 78^{\circ} 05^{\prime} \mathrm{W}\right)$ at $1100-1900 \mathrm{~m}$ (Devenish and Franco 2008). The Reserve is in the Pacific bioregion of Colombia and has been managed for the past 20 years by the Fundación Ecológica los Colibríes de Altaquer (FELCA). The climate is temperate and rainy, with a mean annual temperature of $19^{\circ} \mathrm{C}$ and a mean annual rainfall of ca $8500 \mathrm{~mm}$; July and August are the hottest months. The vegetation in the Reserve contains elements of rainforest $(<1000 \mathrm{~m})$ and montane forest $(>1800$ $\mathrm{m}$ ), and 40.000 ha of the forest between $1100 \mathrm{~m}$ and $1600 \mathrm{~m}$ are therefore regarded as transitional Andean-Pacific forest (Franco-Roselli et al. 1997). There is extensive coverage of primary forest 25-30 m tall in the Reserve, a high density of epiphytic and ground-based plants, a great diversity of flora and fauna, high levels of endemism and numerous watercourses.

Arthropods were sampled by hand, Japanese umbrella device and a Winkler apparatus during two expeditions to the Reserve of 10 days each during October 2009 and May 2010 by biology students under the direction of E. Flórez of the Universidad Nacional de Colombia and the Instituto de Ciencias Naturales. Diplopods were identified to the family level by D. Martínez and E. Flórez following Hoffman et al. 1996, and the species studied by R. Hoffman (see Hoffman et al. 2011). Bryophytes found on diplopods were identified by E. Linares to the lowest possible taxonomic level following Churchill and Linares (1995) for mosses, and Gradstein 


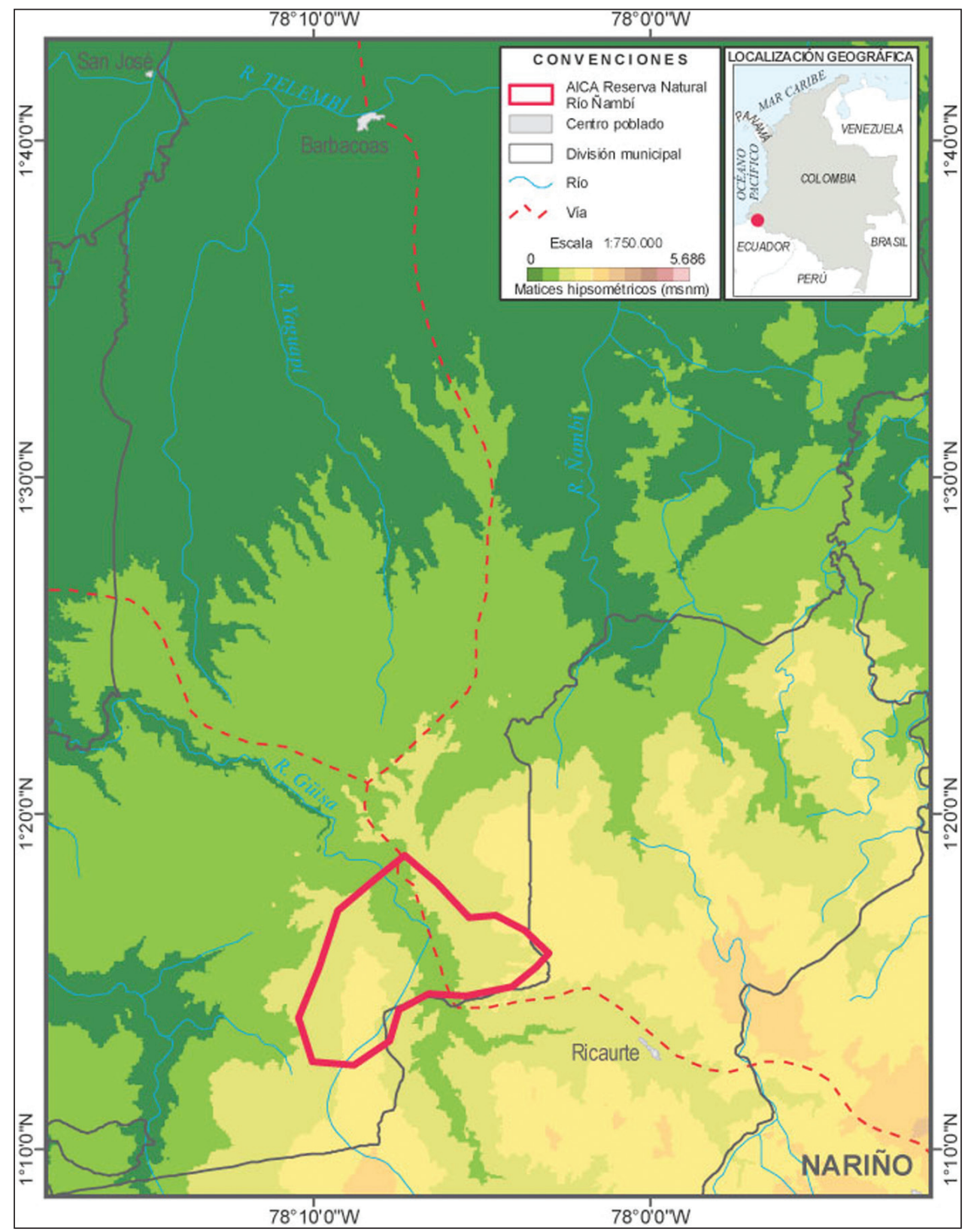

Figure I. Geographical location of the Reserva Natural Río Nambi, borders indicated in red (Devenish and Franco 2008).

et al. (2001) for hepatics. Samples of diplopod-bryophyte associations are preserved in the Myriapodological Collection of the Instituto de Ciencias Naturales, Universidad Nacional de Colombia. 


\section{Results}

The two expeditions produced 124 individuals of Diplopoda belonging to six orders and at least 10 families, of which five families were in Polydesmida (Table 1).

During the process of sorting and identifying the diplopods, it was found that several specimens of Psammodesmus bryophorus (Polydesmida, Platyrhacidae), recently described by Hoffman et al. (2011), were carrying complex mosaics of bryophyte species on their backs (Table 2). In total, 10 species of bryophyte were found firmly attached to the cuticle on 15 P. bryophorus individuals (Table 3).

The most abundant bryophyte families are shown in Fig. 2.

Most of the individuals of $P$. bryophorus were found on tree trunks and living leaves, about $1 \mathrm{~m}$ above the ground, while some were found between litter and the soil surface.

Bryophytes were discovered on most parts of the body (Fig. 3) except the head. Ninety percent were found on the back, with the majority located on the keels, although some were found on the middle of the metatergite. Only six percent were found on the ventral side, towards the base of the legs.

Lepidopilum scabrisetum was not only the most abundant bryophyte species on $P$. bryophorus, but also the species found in the majority of millipede individuals, being present in 68\%, followed by Fissidens weirii and Leujenea sp. 1, which are present in $50 \%$ of individuals (Fig. 4). Leucomium strumosum was only found on one individual.

A male had the highest abundance of bryophytes (55 individual plants) as well as the greatest diversity (seven species) followed by three males with six bryophyte species and a mean abundance of 40 individuals.

Table I. Diplopods found in the Reserva Natural Río Nambí, Colombia.

\begin{tabular}{|c|c|c|c|}
\hline & Order & Families & Individuals \\
\hline & \multirow{5}{*}{ Polydesmida } & Platyrhacidae & 56 \\
\hline & & Chelodesmidae & 6 \\
\hline & & Aphelidesmidae & 4 \\
\hline & & Cryptodesmidae & 1 \\
\hline & & Cyrtodesmidae & 1 \\
\hline & \multirow{2}{*}{ Spirobolida } & Rhinocricidae & 17 \\
\hline & & Not determined & 1 \\
\hline & Spirostreptida & Spirostreptidae & 1 \\
\hline & Stemmiulida & Stemmiulidae & 15 \\
\hline & Glomeridesmida & Glomeridesmidae & 19 \\
\hline & Siphonophorida & Siphonophoridae & 3 \\
\hline Total & 6 & $10+$ & 124 \\
\hline
\end{tabular}

Table 2. Bryophyte-diplopod associations.

\begin{tabular}{l|l|l|l}
\hline P. bryophorus & With bryophytes & Without bryophytes & Total \\
\hline Males & 14 & 6 & 20 \\
\hline Females & 1 & 1 & 2 \\
\hline
\end{tabular}


Table 3. Bryophytes found on 15 specimens of P. bryophorus

\begin{tabular}{l|l|l|l|l}
\hline & Family & Species & Habit & Individual plants \\
\hline \multirow{2}{*}{} & Pilotrichaceae & Lepidopilum scabrisetum (Schwägr.) Steere & Epiphyllous & 247 \\
\cline { 2 - 5 } & Lejeuneaceae & Lejeunea sp. 1 & Epiphyllous & 75 \\
\cline { 2 - 4 } & Fissidentaceae & Fissidens weirii Mitt. & Edaphic & 34 \\
\cline { 2 - 5 } & Lejeuneaceae & Drepanolejeunea sp. 1 & Epiphyllous & 16 \\
\hline & Fissidentaceae & Fissidens steerei Grout & Edaphic & 14 \\
\hline & Lejeuneaceae & Cyclolejeunea & Epiphyllous & 5 \\
\cline { 2 - 5 } & Metzgeriaceae & Metzgeria sp. & Epiphyllous & 3 \\
\cline { 2 - 5 } & Lejeuneaceae & Lejeunea sp. 2 & Epiphyllous & 3 \\
\hline & Lejeuneaceae & Drepanolejeunea sp. 2 & Epiphyllous & 2 \\
\cline { 2 - 5 } & Leucomiaceae & Leucomium strumosum (Hornsch.) Mitt. & Epiphyllous & 2 \\
\hline \multirow{2}{*}{ Total } & 5 & 10 & 2 & 401 \\
\hline
\end{tabular}
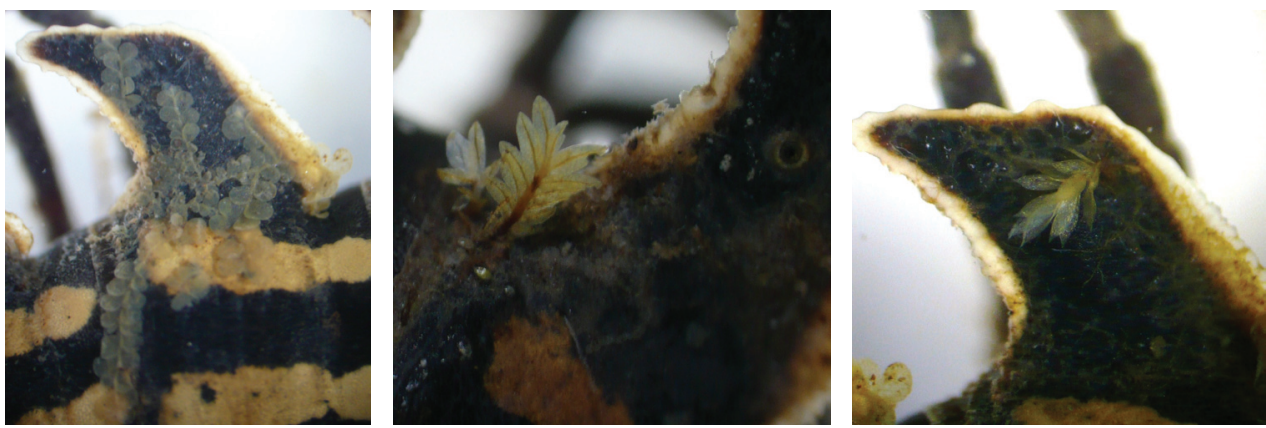

Figure 2. Examples of bryophytes on P. bryophorus. From right to left: Lejeuneaceae, Fissidentaceae, Pilotrichaceae.

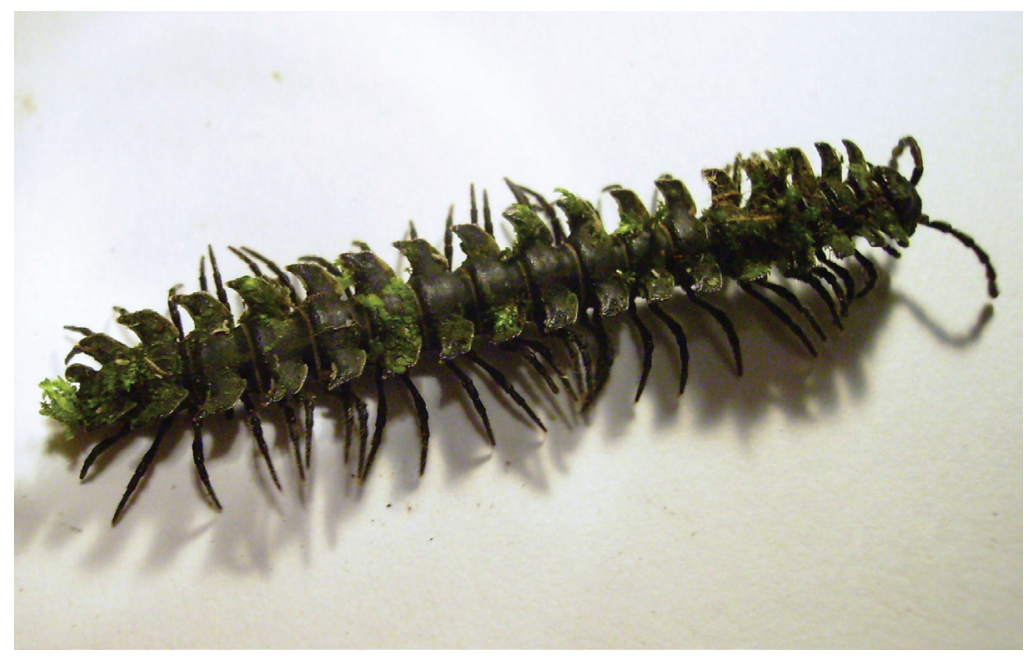

Figure 3. Bryophytes on a P. bryophorus male. 


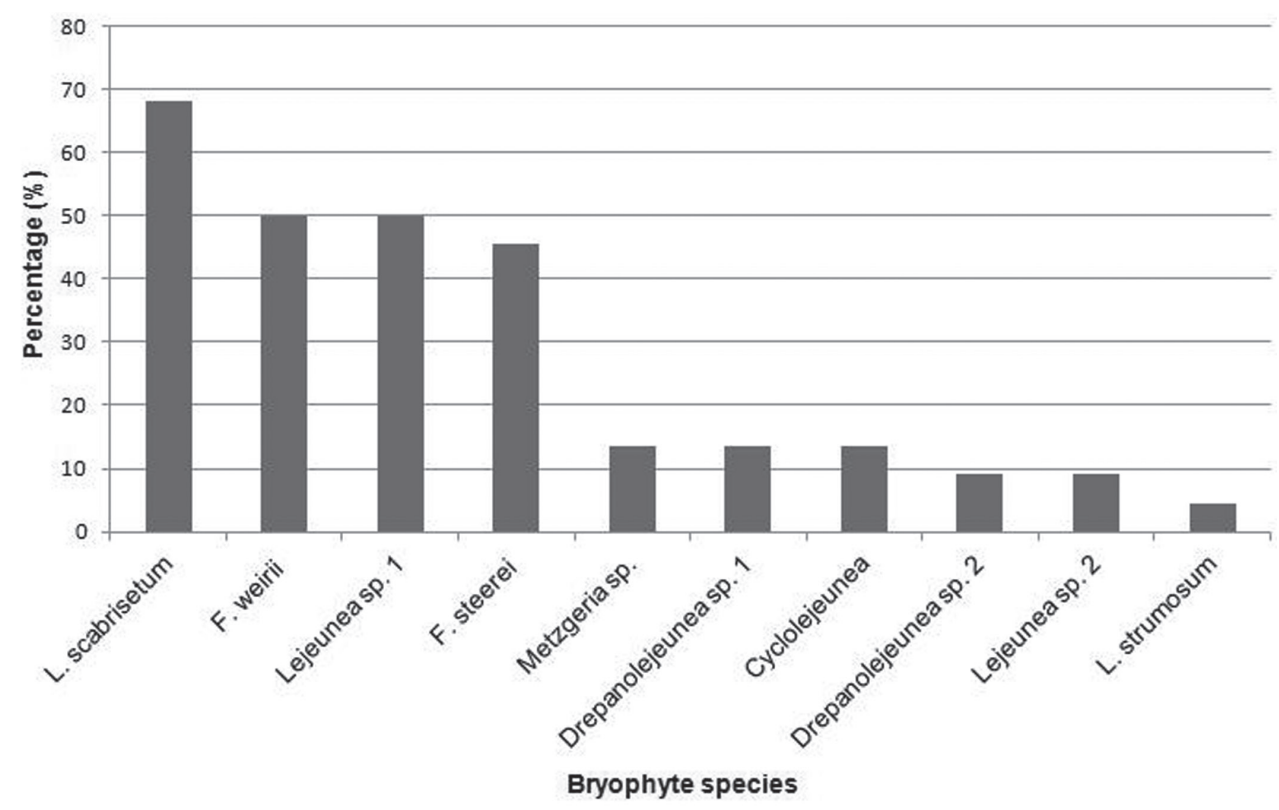

Figure 4. Presence percentage of bryophyte species on P. bryophorus.

\section{Discussion}

Bryophytes do not establish easily on unstable substrates with high decomposition rates, such as litter and soil surfaces in the Reserva forest. It may be that P. bryophorus cuticle serves as a more stable substrate and thus allows the bryophytes to persist and disperse in an otherwise difficult environment. They may also provide a benefit to $P$. bryophorus, which is darkly colored dorsally with two longitudinal light stripes; the epizoic bryophytes may camouflage the diplopod and help protect it from predation as has been reported for other arthropods (Gradstein et al. 1984, Gressitt 1966, Gressitt and Sedlacek 1970, Machado and Vidal 2001).

The Leucomiaceae and Metzgeriaceae families found in this work have already been reported as epizoic bryophytes (Gradstein and Equihua 1995, Machado and Vidal 2001 for the first; and Gressitt et al. 1968 for both) but, to the best of our knowledge, this is the first record of Pilotrichaceae, Leucomiaceae and Fissidentaceae as epizoic bryophytes.

\section{Conclusions}

We have reported here the first known associations of bryophytes with Diplopoda, and one of the few with Arthropoda. It is also, so far as we know, the first reported case of tropical bryophyte entomochory, in which spores and propagules that fell on the backs of diplopods germinated and produced small plants. Most of the epizoic bryophytes we identified are normally epiphytic, but two are normally ground-based near water- 
courses. Finally, none of the previous studies reported multiple species of bryophytes on the same arthropod species, much less on the same individual as found in this study. This may be related to the size of P. bryophorus, which provides a considerable area of bryophyte grown substrate on its body surface.

\section{Acknowledgements}

We thank Dr R. Hoffman, Curator of Invertebrates at the Virginia Museum of Natural History, Martinsville, Virginia, USA, for his assistance with P. bryophorus, Mauricio and Cristian Florez of FELCA for their help with the expeditions and all those who directly or indirectly contributed to this study.

\section{References}

Churchill SP, Linares EL (1995) Prodromus Bryologiae Novo-Granatensis: introducción a la Flora de musgos de Colombia. Biblioteca José Jerónimo Triana No. 12, Parte 1 y 2. Instituto de Ciencias Naturales - Museo de Historia Natural, Facultad de Ciencias, Universidad Nacional de Colombia. Bogotá.

Devenish C, Franco AM (2008) Directorio nacional de AICAS de Colombia. Franco-Roselli P, Betancur J, Fernández-Alonso J (1997) Diversidad florística en dos bosques subandinos del sur de Colombia. Caldasia, 19 (1-2): 205-234. http://www.humboldt.org.co/aicas/ ficha_aica.php?cod=CO068

Gradstein SR, Churchill SP, Salazar N (2001) Guide to the bryophytes of tropical America. Mem. of the New York Bot. Gard. 86.

Gradstein SR, Equihua C (1995) An Epizoic Bryophyte and Algae Growing on the Lizard Corythophanes cristatus in Mexican Rain Forest. Biotropica, Vol. 27, No. 2: 265-268. doi: $10.2307 / 2389005$

Gradstein SR, Vitt DH, Anderson RS (1984) The epizoic occurrence of Daltonia angustifolia (musci) in Papua New Guinea. Cryptogamie, Bryol. Líchenol. 5, 1-2: 47-50.

Gressitt JL (1966) The weevil genus Pantorhytes (Coleoptera), involving cacao pests and epizoic symbiosis with cryptogamic plants and microfauna. Pacific insects 8 (4): 915-965.

Gressitt JL, Samuelson GA, Vitt DH (1968) Moss growing on living Papuan moss-forest weevils. Nature 217: 765-767. doi: 10.1038/217765a0

Gressitt JL, Sedlacek J (1970) Papuan weevil Genus Gymnopholus: Second supplement with studies in epizoic symbiosis. Pacific insects 12 (4): 753-762.

Hoffman R, Golovatch SI, Adis J, de Morais JW (1996) Practical keys to the orders and families of millipedes of the Neotropical region (Myriapoda: Diplopoda). Amazoniana $14(1 / 2): 1-35$.

Hoffman R, Martinez D, Florez E (2011) A new Colombian species in the millipede genus Psammodesmus, symbiotic host for bryophytes (Polydesmida: Platyrhacidae). Zootaxa, 3015: 52-60. 
Ignatov MS, Ignatova EA (2001) On the zoochory of Schistostega pennata (Schistostegaceae, Musci). Arctoa 10: 83-96.

Jofre J, Goffinet B, Marino P, Raguso RA, Shigueo Nihei S, Massardo F, Rozzi R (2011) First evidence of insect attraction by a Southern Hemisphere Splachnaceae: The case of Tayloria dubyi Broth. in the Reserve Biosphere Cape Horn, Chile. Nova Hedwigia 92(3-4): 317-326. doi: 10.1127/0029-5035/2011/0092-0317

Koponen A (1990) Entomophily in the Splachnaceae. Botanical Journal of the Linnean Society 104: 115-127. doi: 10.1111/j.1095-8339.1990.tb02214.x

Lloret F (1990) Colonización de excrementos de bóvido por Tayloria tenuis (With.) Schimp. Anales Jardín Botánico de Madrid 46: 469-476.

Machado G, Vidal DM (2001) On the occurrence of epizoic cyanobacteria and liverworts on a neotropical harvestman (Arachnida: Opiliones). Biotropica 33:535-538.

Rangel O (2004) Colombia diversidad biótica IV. El chochó biogeográfico / Costa Pacífica. Universidad Nacional de Colombia, 41, 977-985. 